\title{
Duration and Mortality Characteristics of Patients with Cerebral Tumors Treated in the Intensive Care Unit of Sanglah General Hospital from January to December 2017
}

\author{
Wayan Widyantara ${ }^{1}$, Gusti Agung Gede Ariswanda', Kadek Sudha Narayana ${ }^{1}$, Ni Nyoman Ayu Trisnadewi ${ }^{1}$, \\ Ida Bagus Kusuma Putra ${ }^{1}$, Ni Putu Witari ${ }^{1}$, Ign Purna Putra ${ }^{1}$, Putu Eka Widyadharma ${ }^{1 \star}$, Ketut Sinardja \\ ${ }^{1}$ Department of Neurology, Faculty of Medicine Udayana University, Sanglah General Hospital, Bali, Indonesia; ${ }^{2}$ Department of \\ Anesthesiology and Reanimation, Faculty of Medicine, Udayana University, Sanglah General Hospital, Bali, Indonesia
}

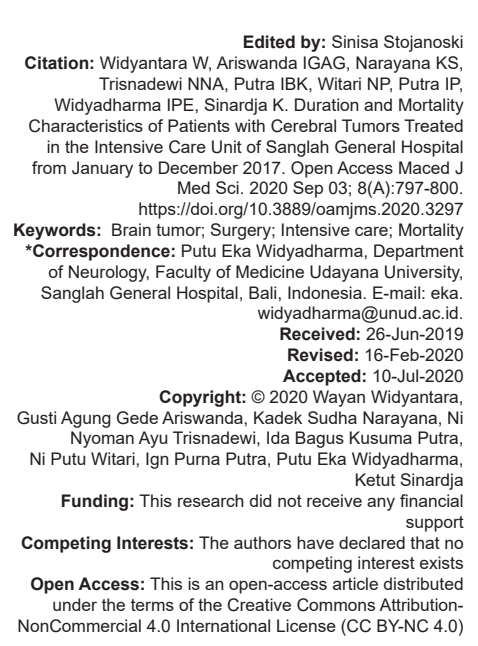

\section{Introduction}

Cerebral tumors or brain tumors are one part of malignant disease, which is increasing in number along with advances in medical technology in terms of diagnosis. The survival rate in patients with cerebral tumors is felt to be increasingly long with emerging supportive and anti-tumor therapies. Causes the problems and complications faced by tumor patients, especially cerebral tumors, and more and more with the need for intensive space also increasing.

The effectiveness of intensive care in tumor or cancer patients is still controversial. Patients with tumors themselves belong to the category of patients with low and vulnerable performance status [1]. Patients with cancer have lower survival rates compared to patients without comorbidities. The mortality rate is also more economical when compared to patients with critical illnesses such as heart failure, liver cirrhosis, or other serious chronic diseases [2]. However, severe complications still cause multiorgan failure in patients with tumors.

The entry of tumor patients into intensive space has increased around the past two decades, around $10-20 \%$ of all patients in intense. Intensivists deal more with tumor patients with dysfunction of organs that enter the fierce, especially the failure of respiratory function, infection, fatal complications, or toxins [2]. About 71 patients with cerebral tumors come the intensive care unit due to refractory seizures (41\%) and septic shock (17\%) [3]. Patients with cerebral tumors also require intensive care before surgery or after the 
procedure. Management of post-operative patients in intensive care causes us to detect rapid neurological deterioration and maintain neurological and systemic homeostasis [4]. The prognosis of patients with cerebral tumors in great space is usually relatively poor. The controversy of economic and ethical issues still places aggressive action in intensive care on patients with oncology, identifying patients that are useful in critical intensive care before entering patients into intensive care [3].

\section{Methods}

This study is a cross-sectional observational study in which all data collection research samples are secondary based on existing medical records. The sample population in this study were cerebral tumor patients who were treated in the intensive care unit at Sanglah General Hospital from January to December 2017 that met the inclusion criteria. Inclusion criteria are patients who have a complete medical record. The sampling technique was carried out by following the type nonrandom sampling method, where all medical records that met the eligibility criteria included as the study sample.

\section{Results}

There were 54 samples of patients with cerebral tumors included in this study. The following is a table of the essential characteristics of tumor patients in intensive space.

The primary characteristics of the study sample based on age, gender, level of education, and occupation shown in Table 1. Table 1 known that cerebral tumor patients treated in intensive space during 2017 were more female $(64.85 \%)$ with the age of most middle-aged adults (41-60 years) as many as 31 patients $(57.4 \%)$ and age early adults (18-40 years) around 16 patients $(29.6 \%)$. The work of most patients does not work, including homemakers, about 22 patients $(40.7 \%)$, with an average education level of fewer than 9 years around $50 \%$ or 27 patients followed by education levels above 9 years around 24 patients (44.4\%).

Based on Table 2, it found that most patients with cerebral tumors included 39 non-glioma tumors $(72.2 \%)$ followed by glioma tumors $(20.4 \%)$ and tumor metastases $(7.4 \%)$. All patients or $100 \%$ received a history of surgical therapy with a Karnofsky 50 score of around 29 cerebral tumor patients $(53.7 \%)$, a score of 40 as many as 20 patients (37\%). Patients with intensive cerebral tumors treated with ventilators were 29 patients $(53.7 \%)$ and without ventilators, around 25 patients $(46.3 \%)$, where the conditions of absolute discharge were all alive, and no complications noted during treatment. The length of stay for patients in intensive care up to 3 days was 45 patients $(83.3 \%)$ and nine patients more than 3 days (16.7\%).

Table 1: Characteristics of cerebri tumor patients in the intensive care unit of Sanglah General Hospital in 2017

\begin{tabular}{ll}
\hline Variable & Respondents (\%) \\
\hline Gender & $19(35.2)$ \\
Male & $35(64.85)$ \\
Female & \\
Age & $3(5.6)$ \\
Teenager & $16(29.6)$ \\
Young adult & $31(57.4)$ \\
Middle adulthood & $4(7.4)$ \\
Old adult & \\
Education & $3(5.6)$ \\
Uneducation & $27(50)$ \\
<9 years & $24(44.4)$ \\
>9 years & \\
Occupation & $22(40.7)$ \\
Unemployment & $9(16.7)$ \\
Civil servant & $10(18.5)$ \\
Entrepreneur & $9(16.7)$ \\
Farmer & $4(7.4)$ \\
Etc. & \\
\hline
\end{tabular}

Table 2: Clinical characteristics of cerebral tumor patients in the intensive care unit of Sanglah General Hospital in 2017

\begin{tabular}{ll}
\hline Variable & Respondents (\%) \\
\hline Diagnosis & $11(20.4)$ \\
Glioma & $39(72.2)$ \\
Non-glioma & $4(7.4)$ \\
Metastases & \\
Therapy & $54(100)$ \\
$\quad$ Surgery & $0(0)$ \\
$\quad$ Non-surgery & \\
Karnofsky score & $2(3.7)$ \\
30 & $20(37)$ \\
40 & $29(53.7)$ \\
50 & $3(5.6)$ \\
60 & $29(53.7)$ \\
Ventilator support & $25(46.3)$ \\
Yes & \\
No & $45(83.3)$ \\
Length of stay & $9(16.7)$ \\
s3 days & \\
>3 days & $54(100)$ \\
Outcome & $0(0)$ \\
Life & $0(0)$ \\
Death & $54(100)$ \\
Complication & \\
Yes & \\
No &
\end{tabular}

The most frequently diagnosed cerebral tumor in the intensive care unit in 2017 according to Table 3 is non-glioma tumors, namely, meningioma, about

Table 3: Diagnosis of cerebral tumors in the intensive care unit of Sanglah General Hospital in 2017

\begin{tabular}{ll}
\hline Variable & Respondents (\%) \\
\hline Diagnosis & $26(48.1)$ \\
Meningioma & $2(3.7)$ \\
Astrocytoma & $5(9.3)$ \\
Glioblastoma multiforme & $1(1.9)$ \\
Ependymoma & $2(3.7)$ \\
Adenoma hipofisis & $4(7.5)$ \\
Cerebellopontine angle tumor & $2(3.7)$ \\
Medulloblastoma & $1(1.9)$ \\
Non-Hodgkin lymphoma & $3(5.6)$ \\
Oligodendroglioma & $4(7.4)$ \\
Brain metastases & $2(3.7)$ \\
Cerebellum tumor & $2(3.7)$ \\
Sarcoma & \\
\hline
\end{tabular}

$48.1 \%$, followed by glioblastoma multiforme tumors in 5 patients $(9.3 \%)$, tumors at the cerebellopontine angle and tumor metastases, respectively, 4 patients $(7.4 \%)$. 


\section{Discussion}

Based on the results of the research data, it found that patients treated in intensive spaces during 2017 were mostly in middle adulthood, which was around 41-60 years old. This is following with a research by Oemiati et al. (2011) where the age increases, the risk of developing a cerebral tumor is higher which reaches its peak around the age of 35-44 years [5]. Epidemiological studies in Iran get the most cases of cerebral tumors at the age of 40 years \pm 19.8 years [6].

Female sex obtained more than men [7]. The process of CAMP synthesis and degradation is different in male and female astrocytic cells for basal cAMP levels [8]. In the animal model, mice found that low cAMP levels supporting the development of tumor cells and drugs that increase cAMP such as rolipram have strong anti-tumor [9], [10], [11], levels were tumorigenesis regulators in neurofibromatosis type 1 (NF1) in optical gliomas [12]. Polymorphism in the adenylate cyclase eight gene correlates with the risk of glioma in NF1, increasing in women, and reducing risk in men [8]. Female patients were predominant than males with a ratio of 1.8:1, resembling of those found in South Korea study [13]. The Department of Neurology at Cipto Mangunkusumo Hospital in 2011-2015 obtained an average age of 48 patients (18-74 years) with a higher proportion of women than men $(55.6 \%$ compared to $44.4 \%$ ). This is slightly different from that reported by McKinney (2004), where it said that male more often diagnosed with cerebral tumors than women with a ratio of 1.5:1 [14]. However, it also explained that women suffer from meningioma more than men. Increased risk of meningioma in women is related to the presence of estrogen, progesterone, and androgen receptors in some types of meningioma. Changes in the size and volume of meningiomas sharply increase in the luteal phase of menstruation and pregnancy, as well as a cessation of contraceptive estrogen agonists in young adults [15].

Patients with a diagnosis of non-glioma primary cerebral tumors found more than glioma tumors and tumor metastases. Of all cerebral tumors, including nonglioma diagnoses, most patients found with meningioma according to Table 3. Based on Central Brain Tumor Registry of the United States data from 2007 to 2011, it noted that meningiomas were the most common tumors in more than $35 \%$ of all adult primary brain tumors followed by glioblastoma (16\%). Anindhita and Wiratma said that the majority of primary tumors are astrocytoma (47\%) followed by meningioma (26\%) [16]. This only illustrates the incidence of patients admitted to intensive care, where there may be more glioma or non-glioma tumor patients who treated intensively outside.

All tumor patients treated in the intensive care unit at Sanglah General Hospital in the period of January-December 2017 are patients who undergo practical actions, which operated more until the $3^{\text {rd }}$ day and came out alive and without complications during intensive care. This shows the role of great space in post-operative care. To treat other severe complications of cerebral tumors, themselves have not been recorded in this period.

\section{Conclusion}

The most brain tumor cases are meningioma, which occurred in women, middle-aged adults with no mortality and complications within 3 days during treatment intensive care.

\section{References}

1. Biskup E, Cai F, Vetter M, Marsch S. Oncological patients in the intensive care unit: Prognosis, decision-making, therapies, and end-of-life care. Swiss Med Wkly. 2017;147(3132):w14481. https://doi.org/10.4414/smw.2017.14558

PMid:28804862

2. Azoulay E, Soares M, Darmon M, Benoit D, Pastores S, Afessa B. Intensive care of the cancer patient: Recent achievements and remaining challenges. Ann Intensive Care. 2011;1(1):5. https:// doi.org/10.1186/2110-5820-1-5 PMid:21906331

3. Tabouret E, Boucard C, Devillier R, Barrie M, Boussen S, Autran D, et al. Neuro-oncological patients admitted in the intensive-care unit: Predictive factors and functional outcome. J Neurooncol. 2016;127(1):111-7. https://doi.org/10.1007/ s11060-015-2015-7

PMid:26608523

4. Lonjaret L, Guyonnet M, Berard E, Vironneau M, Peres F, Sacrista S, et al. Postoperative complications after craniotomy for brain tumor surgery. Anaesth Crit Care Pain Med. 2017;36(4):213-8. https://doi.org/10.1016/j.accpm.2016.06.012 PMid:27717899

5. Oemiati R, Rahajeng E, Kristanto AY. Prevalensi tumour dan beberapa faktor yang mempengaruhinya di Indonesia. Bul Penelit Kesehat. 2012;39(4):190-204

6. Jazayeri SB, Rahimi-Movaghar V, Shokraneh F, Saadat S, Ramezani R. Epidemiology of primary CNS tumors in Iran: A systematic. Asian Pac J Cancer Prev. 2013;14(6):3979-85. https://doi.org/10.7314/apjcp.2013.14.6.3979 PMid:23886218

7. McKinley BP, Michalek AM, Fenstermaker RA, Plunkett RJ. The impact of age and gender on the incidence of glial tumors in New York state from 1976-1995. J Neurosurg. 2000;93(6):9329. https://doi.org/10.3171/jns.2000.93.6.0932

PMid:11117865

8. Warrington NM, Sun T, Luo J, McKinstry RC, Parkin PC, Ganzhorn S, et al. The cyclic AMP pathway is a sex-specific modifier of glioma risk in Type I neurofibromatosis patients. Cancer Res. 2015;75(1):16-21. https://doi.org/10.1158/00085472.can-14-1891

PMid:25381154 
9. Goldhoff P, Warrington NM, Limbrick DD, Hope A, Woerner BM, Jackson E, et al. Targeted inhibition of cyclic AMP phosphodiesterase-4 promotes brain tumor regression. Clin Cancer Res. 2008;14(23):7717-25. https://doi. org/10.1158/1078-0432.ccr-08-0827

PMid:19047098

10. Warrington NM, Gianino SM, Jackson E, Goldhoff $P$, Garbow JR, Piwnica-Worms D, et al. Cyclic AMP suppression is sufficient to induce gliomagenesis in a mouse model of neurofibromatosis-1. Cancer Res. 2010;70(14):5717-27. https:// doi.org/10.1158/0008-5472.can-09-3769 PMid:20551058

11. Yang L, Jackson E, Woerner BM, Perry A, Piwnica-Worms D, Rubin JB. Blocking CXCR4-mediated cyclic AMP suppression inhibits brain tumor growth in vivo. Cancer Res. 2007;67(2):6518. https://doi.org/10.1158/0008-5472.can-06-2762

PMid:17234775

12. Bajenaru ML, Hernandez MR, Perry A, Zhu Y, Parada LF, Garbow JR, et al. Optic nerve glioma in mice requires astrocyte
Nf1 gene inactivation and Nf1 brain heterozygosity. Cancer Res. 2003;63(24):8573-7.

PMid: 14695164

13. Jung KW, Park S, Shin A, Oh CM, Kong HJ, Jun JK, et al. Do female cancer patients display better survival rates compared with males? Analysis of the Korean national registry data, 20052009. PLoS One. 2012;7(12):e52457. https://doi.org/10.1371/ journal.pone.0052457

PMid:23300677

14. McKinney PA. Brain tumors: Incidence, survival, and etiology. J Neurol Neurosurg Psychiatry. 2004;75 Suppl 2:ii12-7. https:// doi.org/10.1136/jnnp.2004.040741

PMid:15146034

15. Wiemels J, Wrensch M, Claus EB. Epidemiology and etiology of meningioma. J Neurooncol. 2010;99(3):307-14. https://doi. org/10.1007/s11060-010-0386-3

PMid:20821343

16. Wiratma AT. Buku Ajar Neurologi. Jakarta: Kedokteran Indonesia; 2017. p. 323-36. 